\title{
Morphometric analysis of ovarian follicles of Black Bengal goats during winter and summer season
}

\author{
MA Bari ${ }^{1}$, ME Kabir ${ }^{1}$, MB Sarker ${ }^{1}$, AHNA Khan ${ }^{2}$ and M Moniruzzaman* ${ }^{1}$ \\ ${ }^{1}$ Department of Animal Science, Bangladesh Agricultural University, Mymensingh 2202, Bangladesh; \\ ${ }^{2}$ Department of Pathology, Bangladesh Agricultural University, Mymensingh 2202, Bangladesh.
}

\begin{abstract}
The present study was undertaken to know the development and degeneration of ovarian follicles in Black Bengal does during winter and summer season. Seven ovaries were collected in each season from a local slaughter house. The ovaries were fixed in $10 \%$ formalin for histological examination. The numbers of different types of follicles obtained during winter and summer season were compared. To compare two sets of data during winter and summer season, independent t-test was performed using Statistical Package for Social Science (SPSS). Histological examination revealed that mean number of antral follicles per ovary was $34 \pm 10(n=7)$ in winter which was higher $(P<0.05)$ than those in summer $(19 \pm 2 ; n=7)$ season. The number of secondary follicles per ovary was also higher $(P<0.05)$ in winter $(52 \pm 5)$ than summer $(35 \pm 10)$ season. During summer season, the ovaries contained $19 \pm 4 \%$ primary and $71 \pm 4 \%$ primordial follicles whereas these values were $52 \pm 3 \%$ and $20 \pm 1 \%$, respectively during winter season. The results indicate that lower rate of development and higher rate of degeneration were occurred in goat ovaries during summer than winter season.
\end{abstract}

Key words: Follicle, goat, ovary, season

Bangladesh Animal Husandry Association. All rights reserved.

Bang. J. Anim. Sci. 2011.39 (1-2): 51-55

\section{Introduction}

Among the Asiatic countries, Bangladesh has the fourth highest population of goats which accounted for about $7.06 \%$ of the total population in Asia (FAO 2003). They are regarded as intimate and integral part of subsistence traditional rural farming system. These indigenous goats have an excellent ability to accommodate and adapt to fluctuation in environment. Although Black Bengal Goats are known as prolific breed, they often show some degree of reproductive failure. Infertility of does in many cases is manifested by abnormalities in the reproductive organs (tract and gonads). Ovaries are vital organ that supplies the germ cells, oocytes and produce hormones for maintaining reproductive health. Primordial germ cells are formed and multiplied during fetal stage. Once these germ cells are differentiated and lose their motility while they are referred to as oogonia. The oogonia are proliferated by mitotic cell division. They enter meiotic cell division and are referred to as oocytes. Oocytes are enclosed by a single layer of squamous granulosa cells to form primordial follicles. Oocytes in primordial follicles grow accompanied by follicular development through primary, secondary and antral stages and are finally ovulated. It is found that remarkably lower numbers of ovarian follicles is considered as one of the major causes of infertility in Black Bengal goats (Amin et al., 2005). The level of reproductive performance depends on the interaction of genetic and environmental factors but this performance is particularly susceptible to latter, for example, the seasonal availability of nutrients can affect reproduction considerably (Riera 1982). Devendra and Burns (1983) stated that ability to accommodate to fluctuation in environment often involves some degree of reproductive failure. Several molecular factors are known to be responsible for the follicular development in mammals (Skinner 2005). The effect of environmental factors on the development of follicles is not understood well. Animals are exposed to adverse climatic conditions, e.g., acute sun shine, high temperature, humidity, rainfall and cool weather in tropical countries like Bangladesh. The effect of such environmental factors on morphology of follicles has not been understood. In Bangladesh, goats are reared under grazing systems by most of the farmers. Here, the temperature ranges from 5 to $15^{\circ} \mathrm{C}$ and from 27 to $38^{\circ} \mathrm{C}$ during winter and summer 
season, respectively. The present study was conducted with a view to compare the follicular development and degeneration in Black Bengal goats' ovaries during winter and summer season.

\section{Materials and Methods}

\section{Collection and processing of ovaries}

Ovaries were collected from adult Black Bengal goats (1-3 years old) at a local slaughter house during winter (January; $n=7$ ) and summer (May; $n=7$ ) season. The Reproductive history of the donor goats was unknown. Before slaughtering, the body conditions of goats were observed, and their body measurements such as length from point of shoulder to pin bone, their height at wither and circumferences of their necks were recorded. Ovaries were kept in collection vial containing phosphate buffered saline solution and transported to the laboratory within $1 \mathrm{hr}$ after collection. Adipose tissues surrounding the ovaries were removed by dissection to clear the ovaries for a better examination. Presence or absence of corpus luteum $(\mathrm{CL})$ and cysts were observed. The length and width of each ovary was measured with the help of Slide Calipers and their weights were also recorded.

\section{Histological procedure}

Fixation: Ovaries were fixed in $10 \%$ formalin for 1 day.

Dehydration: Before dehydration, each ovary was cut into 2 parts. Pieces of ovaries were dehydrated in $50 \%$ alcohol for two hrs, $70 \%$ alcohol for overnight, $80 \%$ alcohol for $1 \mathrm{hr}, 90 \%$ alcohol for $1 \mathrm{hr}$ and absolute (100\%) alcohol for 2 hrs.

Clearing: In this study, xylene was used for this purpose. After proper dehydration, pieces of tissues were immersed in a mixture of equal parts of xylene and alcohol for one hour and again immersed in $100 \%$ xylene for $1 \mathrm{hr}$.

Embedding: Pieces of ovarian tissues were transferred from the clearing agent to a mixture of approximately equal parts of paraffin wax and xylene ( $50 \%$ paraffin wax and $50 \%$ xylene) in the oven set at a temperature from about 50 to $56^{\circ} \mathrm{C}$ for $1.5 \mathrm{hr}$. Ovarian tissues were transferred to pure paraffin wax in the oven for $1.5 \mathrm{hr}$.

Casting the paraffin block: Base plates were adjusted with the angles on the plate to form a mould of a suitable size. The mould was filled with paraffin wax; then tissue was placed and arranged it so that it was set in the right plane for sectioning.

Section cutting and staining: Five $\mu \mathrm{m}$ thick sections were cut by using microtome and were placed in a water bath $\left(30-35^{\circ} \mathrm{C}\right)$, picked upon glass slide and dried in the air. Then sections were deparaffinized with xylene, dehydrated in alcohol and stained with hematoxylin and eosin.

\section{Microscopic observations}

From the serial sections every fifth sections were observed with the help of a light microscope. The number of corpora lutea and different stages of follicles were recorded. The follicles were counted in the section where the oocyte nucleus could be seen. Double counting was avoided. The follicles were classified into four categories according to the number and morphology of granulosa cell layers as: i) Primordial follicles with one layer of flattened granulosa cells surrounding the oocyte; ii) Primary follicles with a single layer of cuboidal granulosa cells; iii) Secondary follicles with two or more layers of granulosa cells but no antrum, and iv) Antral follicles having an antral cavity with multiple layers of granulosa cells.

\section{Statistical analysis}

To compare two sets of data during winter and summer season, independent t-test was performed using Statistical Package for Social Science 11.5 (Statistical Package for Social Sciences, SPSS inc. 1999, Microsoft corporation 1998) in windows Package.

\section{Results and Discussion}

\section{Size and weight of ovary}

The average length, width and weight of ovaries during summer and winter are presented in Table 1. Size and weight of the ovaries did not differ significantly $(P<0.05)$ between these two seasons.

Table 1. Length, width and weight of goat ovary (mean $\pm S D ; n=7$ )

\begin{tabular}{lccc}
\hline Seasons & Length $(\mathrm{cm})$ & Width $(\mathrm{cm})$ & Weight $(\mathrm{g})$ \\
\hline Winter & $1.5 \pm 0.2$ & $1.1 \pm 0.2$ & $0.81 \pm 0.1$ \\
\hline Summer & $1.3 \pm 0.3$ & $0.9 \pm 0.2$ & $0.80 \pm 0.2$ \\
\hline
\end{tabular}

$S D$, standard deviation

Follicular development during winter and summer

In the present study, the numbers of different 


\section{Ovarian follicles of Black Bengal goat}

types of follicles were compared during winter and summer season (Table 2). Histological examination revealed that numbers of primordial and primary follicles were higher $(P<0.05)$ in summer season than winter season and the mean number of antral follicles per ovary was higher $(P<0.05)$ in winter than in summer season (Table 2 ). This indicates that the development of small follicles was lower in winter than summer season. The number of secondary follicles per ovary was higher $(P<0.05)$ in winter than summer. Significant $(P<0.05)$ differences in number of large follicles (secondary and antral follicle) between these two seasons indicate that the rate of follicular development was higher in winter than summer. It is assumed that acute sun shine and high temperature have detrimental effect on ovarian folliculogenesis (Rensis and Scaramuzzi 2003).

Table 2. Number of follicles per ovary during winter and summer season

\begin{tabular}{lcccc}
\hline Seasons & \multicolumn{4}{c}{ Number of follicles (mean $\pm S E, n=7)$} \\
\cline { 2 - 5 } & Primordial & Primary & secondary & Antral \\
\hline \multirow{2}{*}{ Winter } & $159 \pm 6^{\mathrm{a}}$ & $62 \pm 9^{\mathrm{a}}$ & $52 \pm 5^{\mathrm{a}}$ & $34 \pm 10^{\mathrm{a}}$ \\
& $(52.34)$ & $(20.03)$ & $(16.85)$ & $(10.77)$ \\
\hline \multirow{2}{*}{ Summer } & $412 \pm 26^{\mathrm{b}}$ & $116 \pm 29^{\mathrm{b}}$ & $35 \pm 10^{\mathrm{b}}$ & $19 \pm 2^{\mathrm{b}}$ \\
& $(71.27)$ & $(19.46)$ & $(5.87)$ & $(3.40)$ \\
\hline
\end{tabular}

$S E$, standard error; Values in the parentheses indicate the percentage of each category.

\section{Degeneration of follicles during winter and summer}

In the present study, most of the follicles and oocytes were found healthy during winter season. Figure $1 \mathrm{~A}$ represents a healthy antral follicle where granulosa cells were well organized. Oocytes were also healthy with sound nucleus. Figure $1 \mathrm{~B}$ represents a degenerated antral follicle with piknotic oocyte during summer season. Histologically, a number of antral follicles contained degenerated oocytes and abnormal arrangement of cumulus and granulosa cells during summer season. Oocytes in these follicles were floating as those were detached from cumulus and granulosa cells (Figure 1B). This degeneration was thought to be due to heat stress to the does during summer. There is abundant evidence that heat stress can compromise the oocyte and the follicle in which it is encased. Heat stress can alter follicular growth (Roth et al. 2000). Numbers of degenerated follicles were counted in each section. A few numbers of degenerated follicles ( $1 \%$ antral and
$2 \%$ secondary follicles) were found during winter season in this study. On the other hand, $25 \%$ secondary and $13 \%$ antral follicles were found degenerated in histological sections of 7 ovaries during summer season (Figure 2). Numbers of degenerated follicles were higher $(P<0.05)$ during summer season than winter.
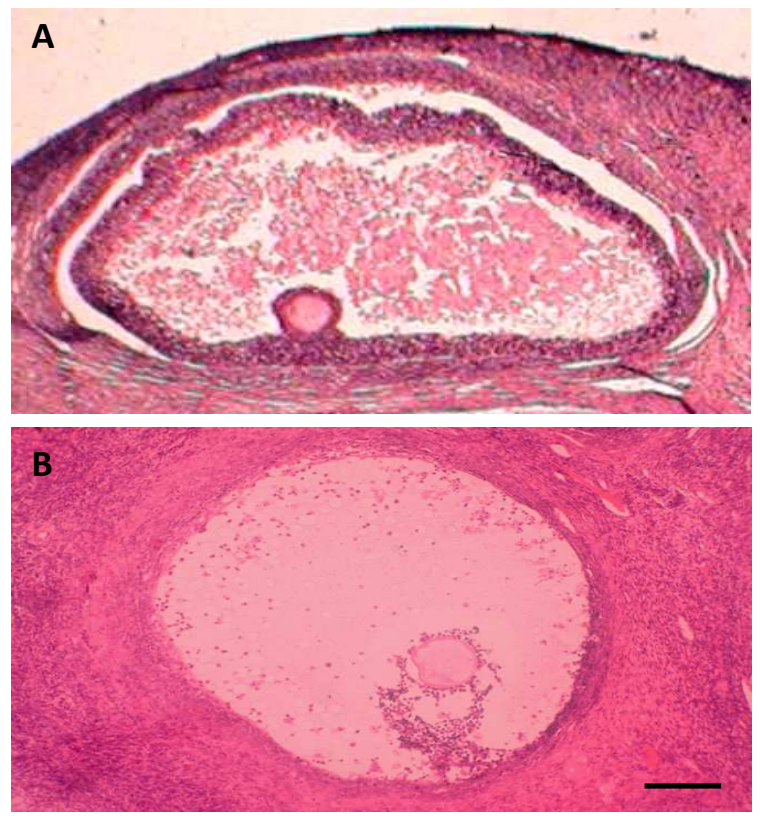

Figure 1. Histological sections of ovaries stained with hematoxylene and eosine. A) A healthy antral follicle in ovary during winter season. B) An abnormal antral follicle during summer season showing degenerating oocyte with few disorganized cumulus cells. Scale bar indicates $100 \mu \mathrm{m}$

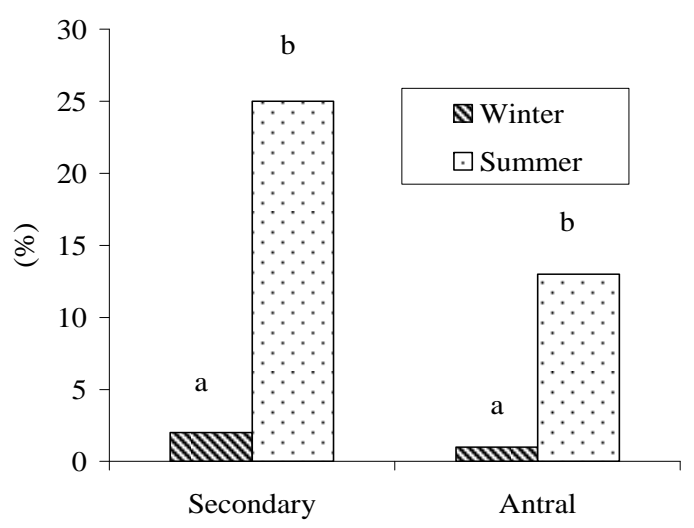

Figure 2. Number of degenerated secondary and antral follicles during winter and summer season; Bars with different 
superscripts ( $a, b)$ within the same category differ significantly $(P<0.05)$

It has been reported that the generation time of granulosa cells is affected by hormonal status and environmental factors such as light, ambient temperature, physical stress, diet and many other variables (Hirshfield 1991). The negative effect of high ambient temperatures on reproductive processes is well documented (Putney et al. 1989; Edwards and Hansen 1997; Lawrence et al. 2004). Wolfenson et al. (1995) reported that heat stress impaired follicular development and altered the dominance of the first-wave dominant follicle and the preovulatory follicle in lactating dairy cattle. The result of the present study showing lower rate of follicular development during summer than winter is in good agreement with the findings of Wolfenson et al. (1995).

Lew et al. (2006) studied hormone concentration and follicular development in dairy cows under seasonal and acute hyperthermia. They evaluated the seasonal and acute heat stress responses on follicular development and steroid, and inhibin concentrations in the follicular fluid of bovine follicles. During summer, the number of viable granulosa cells was $40 \%$ lower than in winter, and there was a $45 \%$ decrease in this parameter during autumn. In the winter, estradiol concentration was $62 \%$ higher than during autumn and $42 \%$ higher than in summer. There was an increase in androstenedione concentration in the summer group compared to winter and autumn groups. Inhibin concentration was higher in winter groups than summer and winter heat stressed groups. Seasonal and acute heat stress altered developmental parameters in dominant follicles and hormonal concentration in follicular fluid, which partially explain the decrease in conception rates during summer. However, seasonal effect on endocrine function or other parameters of follicles was not studied in this study. Precise studies are needed to find out the seasonal or environmental effect on hormone status and over all fertility of does in future.

\section{Conclusion}

The results demonstrate that the rate of follicular development is lower in summer season than winter and number of degenerated follicles is higher in summer season. This lower rate of follicular development and degeneration of oocytes as well as follicles are due to heat stress during summer season. Therefore, this experiment suggests that improved management system avoiding heat stress is needed to obtain high reproductive performance of Black Bengal does.

\section{References}

Amin MR, Salim MS, Khandoker MAMY and Hossain MM (2005). Causes of infertility in Black Bengal does investigated by anatomical and histological tools. Prog. Agric. 16: 117-124.

Devendra C and Burns M (1983). Goat production in the tropics. $2^{\text {nd }}$ edition. Commonwealth Aricultural Bureaux, Farnham House, Farnham Royal, U.K.

Edwards JL and Hansen PJ (1997). Differential responses of bovine oocytes and preimplantation embryos to heat shock. Mol. Reprod. Dev. 46: 138-145.

FAO (Food and Agriculture organization) (2003). Production Yearbook. 57. Rome, Italy.

Hirshfield AN (1991). Development of follicles in the mammalian ovary. Int. Rev. Cytol. 124: 43-101.

Lawrence JL, Payton RR, Godkin JD, Saxton AM, Schrick FN and Edwards JL (2004). Retinol improves development of bovine oocytes compromised by heat stress during maturation. J. Dairy Sci. 87: 2449-2454.

Lew BJ, Meidan R and Wolfenson D (2006). Hormone concentration and follicular development in dairy cow under seasonal and acute hyperthermia. Belo Horizonte, Brazil. 58: 816-822.

Putney DJ, Mullins S, Thatcher WW, Drost M and Gross TS (1989). Embryonic development in superovulated dairy cattle exposed to elevated ambient temperatures between the onset of estrus and insemination. Anim. Reprod. Sci. 19: 37-51.

Rensis, F.D. and Scaramuzzi, R.J. 2003. Heat stress and seasonal effects on reproduction in the dairy cow - a review. Therio. 60: 1139-1151.

Riera D and Peter KE (1982). Ovarian 


\section{Ovarian follicles of Black Bengal goat}

development in prepubertal heifers is influenced by level of dietary intake. Biol. Reprod. 51: 121-124.

Roth Z, Meidan R, Braw-Tal R and Wolfenson D (2000). Immediate and delayed effects of heat stress on follicular development and its association with plasma $\mathrm{FSH}$ and inhibin concentration in cows. J. Reprod. Fertil. 120: 83-90.
Skinner J (2005). Regulation of primordial follicle assembly and development. Hum. Reprod. Update. 11: 461-471.

Wolfenson D, Thatcher WW, Badinga L, Savio JD, Meidan R, Lew BJ, Braw-Tal R and A Berman (1995). Effect of heat stress on follicular development during the estrous cycle in lactating dairy cattle. Biol. Reprod. 52: 1106-1113. 